\title{
Determination of the Hemoglobin F Program in Human Progenitor-derived Erythroid Cells
}

Alan D. Friedman, David C. Linch, Barbara Miller, Jeffrey M. Lipton, Jamshid Javid, and David G. Nathan

Division of Pediatric Hematology and Oncology, Children's Hospital Medical Center, and the Dana Farber Cancer Institute and Department of Pediatrics, Harvard Medical School, Boston, Massachusetts 02115; and Division of Hematology,

Department of Medicine, New York University School of Medicine, New York 10016

\begin{abstract}
The absolute adult and fetal hemoglobin (HbF) contents of the erythroid cells derived from the differentiation of normal human and simian erythroid progenitors and of the peripheral blood erythroid burst-forming units (BFU-E) of patients with nondeletion hemoglobinopathies have been measured with a sensitive radioligand immunoassay. The $\mathrm{HbF}$ content varied between 0.13 and $2.96 \mathrm{pg} /$ cell, representing between $0.7 \%$ and $19.6 \%$ of the total hemoglobin with a mean value of $7.0 \%$. The absolute content of $\mathrm{HbF}$ was indistinguishable in the wellhemoglobinized progeny of marrow erythroid colony-forming units, marrow or blood BFU-E, or of mixed colony-forming units. The term HbF program refers to this inherent capacity to produce fetal hemoglobin (HbF) in the erythroid cells derived from these progenitors in vitro. The $\mathrm{HbF}$ content of marrow erythroblasts as determined by the same radioligand immunoassay was similar to that found in the peripheral blood, suggesting that the switch off of $\gamma$-chain production occurs after the erythroid colony-forming unit stage of maturation. Increasing concentrations of a crude erythropoietin-containing preparation induced higher numbers of erythroid colonies, which were larger in size, but the $\mathrm{HbF}$ program was unaffected. In contrast to the hemoglobin accumulation in human progenitorderived colonies, simian progenitor-derived colonies produced considerably more $\mathrm{HbF}$, and the amount of $\mathrm{HbF}$ was strongly influenced by progenitor maturity. Assays of the HbF content of erythroblasts derived from culture of the peripheral blood BFU-E of patients with nondeletion hemoglobinopathies and their parents showed that the $\mathrm{HbF}$ program in the progenitors of such patients is highly variable. Some produce only a slight excess of $\mathrm{HbF}$ in progenitor-derived erythroblasts, whereas others have extraordinarily high $\mathrm{HbF}$ programs. The molecular basis of this variability is presently unknown.
\end{abstract}

\section{Introduction}

The purpose of the investigations reported here is to assess the inherent capacity of normal adults and those with hemoglobinopathies to produce fetal hemoglobin $(\mathrm{HbF})^{1}$ and thereby

\section{Dr. Javid is with the New York University School of Medicine. Received for publication 1 September 1983 and in revised form 3 December 1984.}

1. Abbreviations used in this paper: BFU-E, erythroid burst-forming unit(s); BPA, burst-promoting activity; CFU-E, erythroid colony-forming unit(s); CFU-GEMM, granulocyte, erythroid, monocyte, macrophage CFU(s); HbA, adult hemoglobin; HbF, fetal hemoglobin; IMDM, Iscove's modified Dulbecco's medium.

J. Clin. Invest.

(c) The American Society for Clinical Investigation, Inc.

$0021-9738 / 85 / 04 / 1359 / 10 \quad \$ 1.00$

Volume 75, April 1985, 1359-1368 to estimate the HbF program within individuals and families. Estimation of this program by means of analysis of the $\mathrm{HbF}$ content of marrow precursors or circulating cells may be misleading. Nearly all of the $\mathrm{HbF}$ in the circulation is packaged in a subset of $F$ erythrocytes or $F$ reticulocytes that contain from 10 to $30 \% \operatorname{HbF}(1,2)$. The number of $F$ cells and their $\mathrm{HbF}$ contents may not reflect the actual capacity of the individual to produce $\mathrm{HbF}$ in erythroid cells because the life span of $F$ cells or $F$ reticulocytes in such hemolytic anemias may radically differ from that of non-F cells (3). Indeed, in some cases of $\beta$-thalassemia, $F$ erythroblasts are apt to be relatively spared the consequences of ineffective erythropoiesis (4). In 1968, Hall and Motulsky (5) demonstrated that marrow cultured in vitro synthesizes more $\mathrm{HbF}$ than is produced in vivo. Later Papayannopoulou and co-workers (6) showed that the progeny of committed adult erythroid progenitors synthesize considerable quantities of $\mathrm{HbF}$. The capacity to measure $\mathrm{HbF}$ in colonies derived in vitro from erythroid progenitors would obviate the problems of selection that confound studies of erythrocytes, reticulocytes, and erythroid precursors in vivo. However, this type of measurement is rendered complex by conflicting observations concerning the influence of progenitor maturity on the amount of $\mathrm{HbF}$ produced in the colonies derived from them. For example, Papayannopoulou and her co-workers (6) concluded that more primitive erythroid progenitors give rise to colonies that contain more $\mathrm{HbF}$ and that the potential to express $\mathrm{HbF}$ is progressively lost during normal erythroid progenitor maturation. It was thus proposed that $\mathrm{F}$ cells are the result of premature commitment to terminal differentiation by progenitors that still have considerable $\mathrm{HbF}$ potential.

That erythroid colonies derived from progenitors synthesize considerable quantities of $\mathrm{HbF}$ has been confirmed in many laboratories, but there have been major discrepancies in the reports of the amount of hemoglobin synthesized and disagreement about the progenitor level at which the ability to synthesize $\mathrm{HbF}$ is lost $(7-18)$. There have also been conflicting reports, using immunofluorescence or hemoglobin synthesis studies, that high concentrations of crude erythropoietin $(11,16,19)$ or supernatants that contain burst-promoting activity (BPA) $(8,15)$ can enhance $\mathrm{HbF}$ synthesis in progenitor-derived colonies.

Just as cell selection confounds assessment of the $\mathrm{HbF}$ program by measurement of $\mathrm{HbF}$ in erythroblasts and circulating cells, studies of $\mathrm{HbF}$ in erythroid colonies may also suffer from technical limitations that lead to the conflicting reports cited above. Immunofluorescent techniques to detect $\mathrm{HbF}$ are essentially qualitative and provide little information about fractional HbF content. Measurement of hemoglobin synthesis in progenitor-derived colonies over a $24-\mathrm{h}$ period has also been severely criticized because of the potential for asynchrony of hemoglobin production during colony devel- 
opment $(14,20-22)$. Differences observed in fractional $\mathrm{HbF}$ synthesis may simply represent different stages of colony development and inadequate total hemoglobin synthesis rather than the intrinsic $\mathrm{HbF}$ program of progenitors themselves. An assay that measures total adult hemoglobin ( $\mathrm{HbA}$ ) and $\mathrm{HbF}$ content can overcome many of these criticisms. The hemoglobin levels measured represent their accumulation during the entire culture period. The maturity of the cells in a given colony or colonies can be assessed by determination of the mean cell hemoglobin level and, because $\mathrm{HbF}$ synthesis precedes $\mathrm{HbA}$ synthesis, the total HbF capacity is nearly attained whether the cells in the colony are fully mature or not. Using the radioligand immunoassay for $\mathrm{HbA}$ and $\mathrm{HbF}$ developed by Javid et al. (23), Macklis and co-workers (24) examined the hemoglobin contents of different classes of erythroid progenitorderived colonies in the rhesus monkey. Their studies showed that in this species there is indeed a progressive increase in $\mathrm{HbF}$ content of erythroid colonies as a function of progenitor immaturity.

Here we demonstrate that, in the culture system that we describe, the erythroid colonies derived from a broad range of human progenitors produce nearly equal amounts of $\mathrm{HbF}$, and that this $\mathrm{HbF}$ production is independent of the effects of erythropoietin. Therefore, we have begun to apply this assay to determine the $\mathrm{HbF}$ program in the erythroid progenitors of patients with hemoglobinopathies.

\section{Methods}

Blood and marrow samples. Marrow samples were obtained from two patients in remission from acute lymphoblastic leukemia, from two young adult Macaca fascicularis (kindly made available by Dr. Norman Letvin, New England Regional Primate Center, Southboro, MA) and from 10 normal Caucasian volunteer donors who gave their informed consent. Blood samples were also obtained from the marrow donors, from seven other normal Caucasian individuals, and from five patients (and three of their parents) with $\beta$-thalassemia or sickle cell anemia.

Mononuclear cell preparation. Blood and marrow samples were diluted with tissue culture medium (Iscove's modified Dulbecco's medium, IMDM), layered over Ficoll-Hypaque (Pharmacia Fine Chemicals, Piscataway, NJ), and centrifuged for $20 \mathrm{~min}$ at $1,200 \mathrm{~g}$ at room temperature.

The cells at the interface were collected, washed three times with cold IMDM with $5 \%$ fetal calf serum, counted with a hemocytometer, and resuspended in the serum-fortified IMDM at 10 times the desired plating concentration.

Preparation of early erythroblast-enriched marrow fraction. FicollHypaque-separated bone marrow cells were treated with TG-1 monoclonal antibody and complement to remove cells of the granulocytic and monocytic lineages (25). Residual cells bearing receptors for sheep erythrocytes and cells bearing receptors for the Fc portion of immunoglobulin $\mathrm{G}$ (IgG) were then removed by serial rosetting with 2 amino-ethylisothiouronium bromide-treated sheep cells and IgG-coated sheep cells followed by density separations over Ficoll-Hypaque.

Methylcellulose culture of mononuclear cells. Cells were plated at $1-2 \times 10^{5}$ cells $/ \mathrm{ml}$ in $35-\mathrm{mm}$ petri dishes (Falcon Labware, Becton, Dickinson \& Co., Oxnard, CA) in a mixture containing $0.9 \%$ methylcellulose, 30\% fetal calf serum (Gibco Laboratories, Grand Island, $\mathrm{NY}$ ), $9.0 \mathrm{mg} / \mathrm{ml}$ deionized bovine serum albumin (Sigma Chemical Co., St. Louis, MO, fraction V), $1.4 \times 10^{-4} \mathrm{M} \beta$-mercaptoethanol, 5\% Mo cell line-conditioned medium as a source of BPA (generously provided by David Golde, University of California Los Angeles School of Medicine, Los Angeles, CA) and with crude erythropoietin (Toyobo) in IMDM. Marrow erythroid burst-forming units (BFU-E) and blood BFU-E were all induced to form colonies in the continuous presence of $2.0 \mathrm{U}$ of erythropoietin per $/ \mathrm{ml}$, erythroid colony-forming units (CFU-E) in 0.5 and $2.0 \mathrm{U}$, and granulocyte, erythroid, monocyte, macrophage CFU(s) (CFU-GEMM) in the presence of $1.0 \mathrm{U}$ of erythropoietin per $/ \mathrm{ml}$. The plates were incubated in humidified $4 \%$ $\mathrm{CO}_{2}$ at $37^{\circ} \mathrm{C}$. Marrow CFU-E-derived colonies were cultured for 7-8 d whereas peripheral blood and marrow BFU-E-derived colonies were cultured for $14 \mathrm{~d}$. For growth of CFU-GEMM colonies, 5\% (vol/vol) giant cell tumor-conditioned medium (Gibco Laboratories) as a source of colony-stimulating activity and 5\% Mo cell line-conditioned medium as a source of BPA were included in the culture mixture from its inception, but the addition of erythropoietin was delayed until days 3-5 when $1 \mathrm{U} / \mathrm{ml}$ was added. The culture was then continued for a total of $14 \mathrm{~d}$.

Sample preparation for hemoglobin assay. Erythroid colonies $(\sim 20$ BFU-E- or CFU-GEMM-derived and 100-200 CFU-E-derived) were plucked with a drawn out pasteur pipette, pooled in $0.3-0.5 \mathrm{ml}$ of IMDM, $4^{\circ} \mathrm{C}$, and resuspended. $20 \mu \mathrm{l}$ of this was taken for cell counting in a hemocytometer. A precisely measured volume was then transferred to a second tube and pelleted. The supernatant was carefully aspirated with a drawn out pipette and the pellet was resuspended in a precisely measured volume of $0.5 \mathrm{mg} / \mathrm{ml}$ carrier sheep hemoglobin (300-400 ml) containing $0.02 \% \mathrm{Na}$-azide. This suspension was sonicated in an Eppendorf tube, microcentrifuged to remove cell debris, and stored at $4^{\circ} \mathrm{C}$. Samples were routinely assayed within $10 \mathrm{~d}$ of preparation. In some experiments, intermediate and well-hemoglobinized BFU-E-derived colonies were removed separately and pooled.

Hemoglobin preparation, assay, and $\mathrm{HbF}$ determination. Hemoglobin from adult blood, cord blood, or sheep blood samples were obtained by $\mathrm{CCl}_{4}$ lysis of washed cells, the stroma being removed by centrifugation. Fresh samples were prepared every $3 \mathrm{wk}$. The hemoglobin concentration was measured spectrophotometrically as cyanmethemoglobin and the percentage of $\mathrm{HbF}$ was determined by alkali denaturation. The adult and cord blood samples were used to construct standard curves.

Radioligand immune assay for $\mathrm{HbA}$ and $\mathrm{HbF}$. $\mathrm{HbA}$ and $\mathrm{HbF}$ standards were prepared as above and diluted with $0.5 \mathrm{mg} / \mathrm{ml}$ sheep hemoglobin. Sonicated cell extracts derived from erythroid colonies were also diluted with $0.5 \mathrm{mg} / \mathrm{ml}$ sheep hemoglobin. 2-3 dilutions were routinely assayed as previously described (23).

Linear standard curves were consistently obtained, and the hemoglobin in 3,000-10,000 cells was routinely assayed. Dilutions of a given sample or the same sample assayed on separate days yielded results within $10 \%$ of the mean. Though the majority of samples analyzed represent colonies pooled from duplicate or triplicate plates, when individual plates were examined the variability of percentage of $\mathrm{HbF}$ between plates was $<10 \%$ of the mean value.

A further error was induced by estimation of the total hemoglobin or $\mathrm{HbF}$ per cell in these erythroid colonies. The reliability of this determination was based upon the accuracy of enumeration of erythroid cells in the hemocytometer. The variability of this procedure was found to be $\sim 5-10 \%$, but was no less than $10 \%$ with respect to CFUGEMM colonies in that this required an additional assessment of the percentage of erythroid cells within the pooled colonies. It must be emphasized that the expression picograms of total hemoglobin or $\mathrm{HbF}$ per cell utilized in this report represents a mean value and not the actual concentration in each cell. Some samples of our pooled colonies were kindly examined by Dr. George Dover, Johns Hopkins University School of Medicine, Baltimore, MD, who found that $\sim 50 \%$ of the cells in either CFU-E or BFU-E derived colonies had undetectable levels of hemoglobin $F(<3 \mathrm{pg} /$ cell). This $50 \%$ detectable $\mathrm{F}$ cell frequency is a value similar to that which Dover et al. (26) reported previously. We cannot know whether the cells that apparently contain no $\mathrm{HbF}$ are actually $\mathrm{F}$ cells with an amount of $\mathrm{F}$ that is below the level of detection. Therefore, we report our results as mean values for the entire population recognizing that the actual mean amount of $\mathrm{HbF}$ per $\mathrm{F}$ cells might be twice the mean value reported here.

\section{Results}

Culture characteristics. Under the culture conditions used in this study, human CFU-E-derived colonies become well hemo- 
Table I. Erythroid Colony Frequency, Size, and Hemoglobin Content

\begin{tabular}{lcccr}
\hline & No. of experiments & $\begin{array}{l}\text { Colonies/10 } \\
\text { Ficoll-Hypaque-separated cells }\end{array}$ & Average cells/colony & HbT* \\
\hline CFU-E & 7 & $168 \pm 28$ & $651 \pm 480$ & $13 \pm 3.1$ \\
Marrow BFU-E & 10 & $128 \pm 54$ & $9,120 \pm 613$ & $18.3 \pm 5.8$ \\
Blood BFU-E & 5 & $32 \pm 14$ & $12,300 \pm 5,700$ & $22.6 \pm 3.2$ \\
CFU-GEMM & 6 & $2.0 \pm 1.1$ & $24,900 \pm 11,500 \ddagger$ & $18.5 \pm 2.4$
\end{tabular}

The data represent the means and standard deviations of erythroid progenitor-derived colony frequencies and sizes (as estimated from the number of erythroid cells per colony) and the total hemoglobin content per cell within each class of colony. The data presented in Fig. 3 are excluded from this compilation. The erythroid cells per colony are higher than those generally reported for either plasma clot or methylcellulose cultures, particularly for CFU-E-derived colonies. Under the culture conditions that presently obtain in our laboratory, CFU-E colonies have $155 \pm 54$ cells, but both $\mathrm{HbT}$ and $\mathrm{HbF}$ contents remain the same. * Total picograms of hemoglobin per erythroid cell. $\ddagger$ Total cells of which an average of $62 \%$ were erythroid.

globinized (appearing dark red) after 7-8 d and lysed by 10$12 \mathrm{~d}$, whereas human blood- and marrow-derived BFU-E colonies and CFU-GEMM colonies become well hemoglobinized at $12-15 \mathrm{~d}$ of culture. Simian CFU-E-derived colonies are fully developed at $5 \mathrm{~d}$ and BFU-E-derived colonies at 8-10 d. Over $98 \%$ of cells from CFU-E and BFU-E are erythroid. Cytocentrifugates of such mature CFU-E- or BFU-E-derived colonies show a similar cellular profile with a complete spectrum of cells from proerythroblasts to enucleated red cells. Cytocentrifugates of poorly hemoglobinized BFU-E colonies plucked at day 10 show a preponderance of proerythroblasts. The average colony yields, colony sizes, and hemoglobin contents per cell in this study are shown in Table $I$. The values for colony frequency compare very favorably with those obtained in other laboratories, although the CFU-E-derived colony numbers obtained in methylcellulose are less than those seen in the plasma clot assays of the same sorts of marrows employed in our laboratory. As emphasized in Table I, the mean CFU-E-derived colony size reported is higher than expected. In more recent experiments such as those described in Fig. 3 and its legend, CFU-E-derived colony size was considerably lower, though the hemoglobin contents remain the same. As will be seen below, the hemoglobin content of a mixed population of marrow erythroblasts is $\sim 18 \mathrm{pg} /$ cell, and this is the value often observed by us in the erythroid cells derived from immature progenitors. This was also the amount observed by Javid and Pettis (27), but is considerably higher than the hemoglobin contents estimated by Dean and coworkers (28), who also utilized a radioimmunoassay to measure total hemoglobin and $\mathrm{HbF}$ in immature progenitor-derived colonies.

$\mathrm{HbF}$ and $\mathrm{HbA}$ content of erythroid colonies grown in vitro. Fig. 1 presents the total hemoglobin and $\mathrm{HbF}$ per erythroid cell in well-hemoglobinized erythroid colonies derived from 7-d (CFU-E) and 14-d (BFU-E) derived colonies. These were collected from seven different pairs of normal marrow cultures. The total hemoglobin and $\mathrm{HbF}$ in picograms per cell as well as the percentage of $\mathrm{HbF}$ are indicated for each separate pooled culture and the data are presented as a function of total colony size. The results of the measurements of hemoglobin in the 7- and 14-d derived colonies are shown for each pair. The amount of hemoglobin accumulated in the cells collected from the 14-d colonies is somewhat higher than that which accumulates in the 7-d colonies. $(P=0.05$ by the Wilcoxon paired test). This effect increases the fraction but not the absolute amount of $\mathrm{HbF}$ in CFU-E-derived colonies beyond that found in BFU-E-derived colonies.

Fig. 2 presents an analysis of the hemoglobin contents of erythroid colonies derived from peripheral blood BFU-E and marrow CFU-GEMM. These data and those in Fig. 1 demonstrate that the production of $\mathrm{HbF}$ in picograms per cell is very limited in the colonies derived from human erythroid progenitors and is not influenced by the time of appearance or tissue of origin of a colony, colony size, colony morphology, or the presence of nonerythroid cells within a colony. These are characteristics that reflect the stage of maturation of the progenitor of the colony. These progenitor-derived erythroid cells produce $<3 \mathrm{pg}$ of $\mathrm{HbF}$ per cell, and this usually constitutes a low fraction of the total hemoglobin per cell.

A possible limitation to the studies presented in Figs. 1

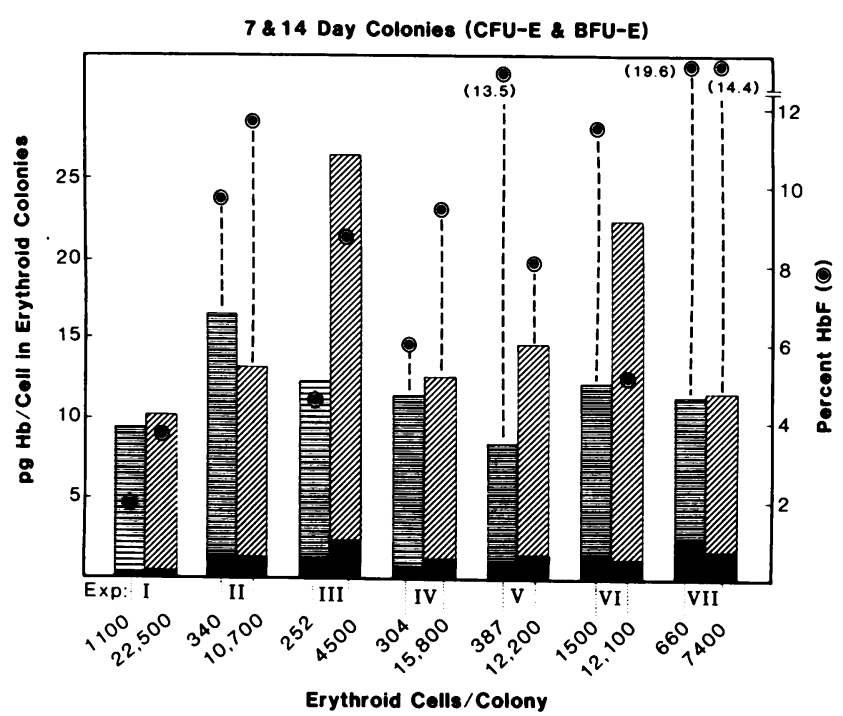

Figure 1. The total accumulation of hemoglobin and $\mathrm{HbF}$ in erythroid colonies derived from marrow CFU-E and BFU-E. The number of erythroid cells in each colony is shown on the abscissa. The left hand ordinate represents the hemoglobin in picograms per erythroid cell in each type of erythroid colony. The height of each bar represents the total hemoglobin. The height of the solid black portion of the bar represents the HbF accumulation per cell. (目, 四) CFU-Eand BFU-E-derived colonies, respectively. $(\odot)$ Percentage of F. It is either attached by a dotted line to or within the bar to which it corresponds. 


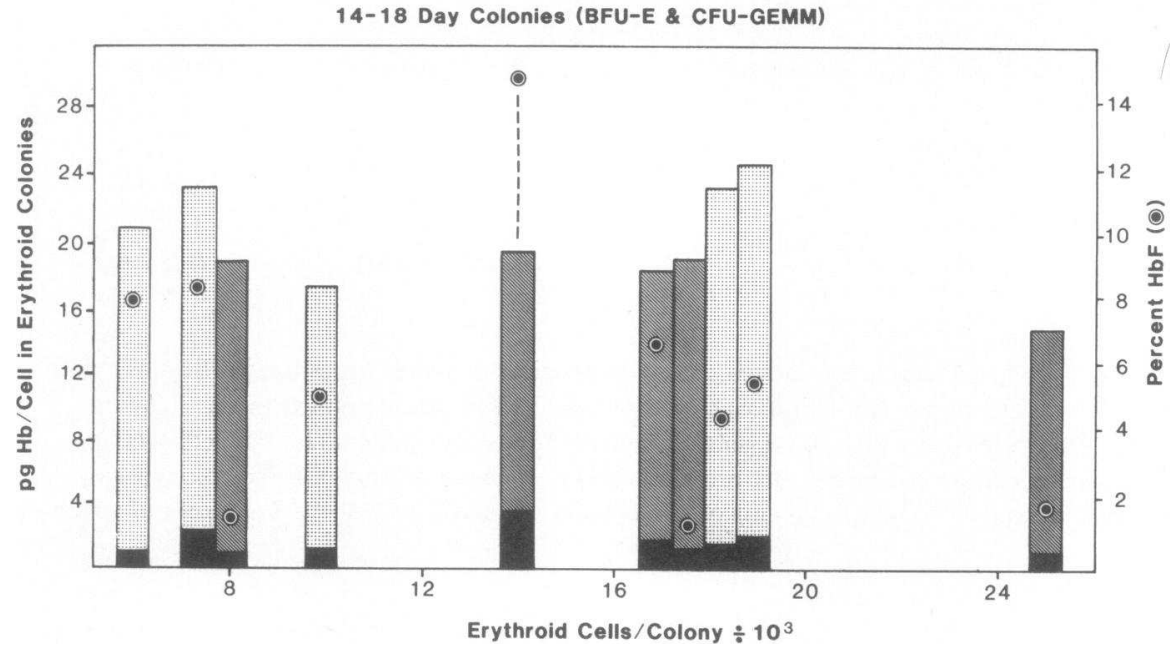

Figure 2. The total accumulation of hemoglobin and of $\mathrm{HbF}$ in peripheral blood, BFU-E, and marrow CFU-GEMM-derived colonies of eight individuals. ( $\square$, $₫)$ BFU-Eand CFU-GEMM-derived colonies, respectively. See legend to Fig. 1 for further details. and 2 was that some CFU-E-derived colonies could survive until $14 \mathrm{~d}$ and obscure any difference in the hemoglobin content of the BFU-E. In three experiments therefore, all wellhemoglobinized colonies were sterilely removed from the culture plates before day 12 and the plates were then incubated for several more days. A cohort of new well-hemoglobinized BFU-E colonies could then be obtained wihout any risk of CFU-E colony contamination. When these colonies were analyzed there was again no significant difference between the CFU-E- and BFU-E-derived colony HbF contents (Table II). Another possible source of confusion might have arisen as a result of contamination of well-hemoglobinized CFU-E colonies at day 7 by the immature products of BFU-E colony formation undergoing asynchronous hemoglobin synthesis or by the fact that some of the larger 7-d colonies inherently represent the BFU-E-derived colonies. Such BFU-E-derived colonies might have contributed $\mathrm{HbF}$ but not $\mathrm{HbA}$ to the CFU-E-derived colony hemoglobin. But studies of peripheral blood BFU-Ederived colonies from day 7 through day 14 , uncontaminated by CFU-E-derived colonies because CFU-E are not present in blood, demonstrate that $\mathrm{HbF}$ is barely detectable in them at day 7 (data not shown). Therefore, we conclude that values displayed in Figs. 1 and 2 fairly represent the actual hemoglobins that accumulated in the indicated colonies.
It has been suggested that the BFU-E circulating in the peripheral blood are more primitive than most marrow BFUE (29), and a previous study in our laboratory in which we measured fractional $\mathrm{HbF}$ synthesis suggested that it was considerably higher in blood-derived BFU-E colonies than in marrow BFU-E colonies (11). The $\mathrm{HbF}$ and $\mathrm{HbA}$ content of paired samples of well-hemoglobinized blood and marrow BFU-E colonies were therefore determined for four individuals, and the results are given in Table III. As predicted from the data in Fig. 1 no significant difference was seen.

In a further series of experiments the blood or marrow CFU-GEMM colonies of six individuals were isolated and the hemoglobin content in the cells of pooled colonies compared with that found in paired cultures of blood or marrow BFU-E. A cytocentrifugate was also made of the pooled mixed colonies to determine their percentages of erythroid cells. The average $\mathrm{HbA}$ and $\mathrm{HbF}$ content per erythroid cell is shown in Table IV where it is apparent that the percentage of $\mathrm{HbF}$ content of CFU-GEMM-derived colonies is similar to the corresponding BFU-E-derived colonies. CFU-GEMM may be induced to form colonies after delayed erythropoietin addition. Therefore, in three experiments BFU-E-derived colonies were also plucked from these plates. The hemoglobin content of these BFU-E-derived colonies did not differ significantly from

Table II. Hemoglobin Content of Bone Marrow CFU-E- and BFU-E-derived Colonies After Removal of Early Hemoglobinized Colonies

\begin{tabular}{|c|c|c|c|c|c|c|c|c|}
\hline \multirow{3}{*}{$\begin{array}{l}\text { Exp. } \\
\text { no. }\end{array}$} & \multirow{2}{*}{\multicolumn{3}{|c|}{ CFU-E }} & \multicolumn{5}{|l|}{ BFU-E } \\
\hline & & & & \multirow{2}{*}{$\begin{array}{l}\text { Removal } \\
\text { day }\end{array}$} & \multirow{2}{*}{$\begin{array}{l}\text { Assay } \\
\text { day }\end{array}$} & \multirow[b]{2}{*}{$\mathrm{HbF}$} & \multirow[b]{2}{*}{$\mathrm{HbT}$} & \multirow[b]{2}{*}{$\% \mathrm{HbF}$} \\
\hline & $\mathrm{HbF}$ & $\mathrm{HbT}$ & $\% \mathrm{HbF}$ & & & & & \\
\hline & $H b / c e l l(p g)$ & $H b / c e l l(p g)$ & Hb/cell (pg) & & & $H b / c e l l(p g)$ & $\mathrm{Hb} / \mathrm{cell}(\mathrm{pg})$ & $\mathrm{Hb} / \mathrm{cell}(\mathrm{pg})$ \\
\hline 3 & 1.19 & 12.3 & 9.7 & 12 & 15 & 1.57 & 10.5 & 14.9 \\
\hline 4 & 0.78 & 11.6 & 6.7 & 10 & 14 & 1.28 & 10.5 & 12.2 \\
\hline \multirow{2}{*}{5} & 1.11 & 8.2 & 13.5 & $8(a)$ & 14 & 0.6 & 11.8 & 5.1 \\
\hline & & & & $8(b)$ & 17 & 1.31 & 26.2 & 5.0 \\
\hline
\end{tabular}

The CFU-E-derived colonies were plucked in separate cultures and assayed at $7 \mathrm{~d}$. The BFU-E designated cultures were cultured beyond $7 \mathrm{~d}$ for from $5 \mathrm{~d}$ (exp. 3) to $1 \mathrm{~d}$ (exp. 5). At this point, all well-hemoglobinized colonies were removed to eliminate any residual CFU-E-derived colonies that might not have lysed. Then the cultures were continued for a further 3 (exp. 3) to 9 (exp. $5 b$ ) days. The residual BFU-E-derived colonies, presumably freed of CFU-E-derived colonies by a combination of lysis and mechanical removal, were then analyzed. 
Table III. Comparison of Hemoglobin Content of Marrow and Blood BFU-E-derived Colonies

\begin{tabular}{|c|c|c|c|c|c|c|}
\hline \multirow[b]{2}{*}{ Exp. no. } & \multicolumn{3}{|c|}{ Marrow BFU-E } & \multicolumn{3}{|l|}{ Blood BFU-E } \\
\hline & $\mathrm{HbF}$ & HbT & $\% \mathrm{HbF}$ & $\mathrm{HbF}$ & $\mathrm{HbT}$ & $\% \mathrm{HbF}$ \\
\hline & $H b / c e l l(p g)$ & $\mathrm{Hb} / \mathrm{cell}(\mathrm{pg})$ & $\mathrm{Hb} / \mathrm{cell}(\mathrm{pg})$ & $H b / c e l l(p g)$ & Hb/cell (pg) & $\mathrm{Hb} / \mathrm{cell}(\mathrm{pg})$ \\
\hline 6 & 1.12 & 22.5 & 5.0 & 1.8 & 22.5 & 8.0 \\
\hline 8 & 0.67 & 20.4 & 3.3 & 1.10 & 27.7 & 4.0 \\
\hline 9 & 0.45 & 16.1 & 2.8 & 0.91 & 17.0 & 5.3 \\
\hline 10 & 1.78 & 21.7 & 8.2 & 0.89 & 20.2 & 4.4 \\
\hline Mean \pm SD & $1.0 \pm 0.5$ & $20.2 \pm 2.5$ & $4.8 \pm 2.1$ & $1.2 \pm 0.4$ & $21.9 \pm 3.9$ & $5.4 \pm 1.6$ \\
\hline
\end{tabular}

The results are from paired cultures of the blood and marrow of four separate individuals. The differences between the means are not statistically significant.

those grown with erythropoietin from the onset of culture (data not shown).

Comparison of $M$. fascicularis and human progenitorderived colonies. Because culture conditions vary between and within laboratories we reinvestigated the findings of Macklis et al. (24) and compared cultures of the marrow of $M$. fascicularis to human marrow cultures prepared with identical reagents. The marrow CFU-E- and BFU-E-derived colonies of two separate simian marrow cultures were plucked and pooled on days 5 and 8 , respectively, and of four human marrows on days 7 and 14, respectively. The human marrows were in addition to those included in Table $I$ and described above. The results shown in Fig. 3 clearly demonstrate a major difference between simian and human progenitors with respect to the HbF program. Simian BFU-E-derived colonies have much higher $\mathrm{HbF}$ contents than do those of humans. The difference remains but is less dramatic at the level of CFU-E because the $\mathrm{HbF}$ program expressed in simian CFU-E-derived colonies is much lower than in BFU-E. In contrast, the HbF program expressed in the four different samples of human erythroid progenitor-derived colonies is relatively constant whether the colonies arise from BFU-E or CFU-E. In this study, CFU-E-derived colonies were considerably smaller than those described above.
In these studies of simian marrow, adherent cells were removed from an aliquot of the low-density cell fractions before their culture. No influence of this maneuver on the $\mathrm{HbF}$ accumulation could be detected (data not shown).

Hemoglobin content of marrow erythroblasts. The peripheral blood of marrow 7 in Fig. 1 contained $<2 \% \mathrm{HbF}$ although the erythroid colonies grown in vitro contained between 14.4 and $19.6 \% \mathrm{HbF}$. Therefore, an early erythroblast-enriched marrow fraction was made and the $\mathrm{Hb}$ content per erythroid cell was determined. The average erythroid cell hemoglobin was 18.9 pg per cell with $<1$ pg $\mathrm{HbF}$ per cell (a barely detectable amount). The erythroblast hemoglobin $F$ content of another marrow was undetectable compared with $5.2 \%$ found in its CFU-E-derived colonies. These findings suggest that the $\mathrm{HbF}$ program is markedly diminished beyond the CFU-E stage of erythroid maturation. The basis of this conclusion is discussed below.

Effects of erythropoietin on hemoglobin accumulation in vitro. Four separate samples of bone marrow BFU-E-derived erythroid colonies were cultured at $0.1,0.2$, and 0.5 , and 2.0 $\mathrm{U}$ of erythropoietin per $\mathrm{ml}$ and the average $\mathrm{HbF}$ and $\mathrm{HbA}$ contents per cell for these samples were determined. Increased erythropoietin clearly caused more colonies to grow and caused these colonies to be larger. For example, at $0.2 \mathrm{U}$ erythropoietin

Table IV. Comparison of Hemoglobin Content of BFU-E- and CFU-GEMM-derived Colonies

\begin{tabular}{|c|c|c|c|c|c|c|c|}
\hline \multirow[b]{2}{*}{ Exp. no. } & \multirow[b]{2}{*}{ Source* } & \multicolumn{3}{|l|}{ BFU-E } & \multicolumn{3}{|l|}{ CFU-GEMM } \\
\hline & & $\mathrm{HbF}$ & $\mathrm{HbT}$ & $\% \mathrm{HbF}$ & $\mathrm{HbF}$ & $\mathrm{HbT}$ & $\% \mathrm{HbF}$ \\
\hline & & Hb/cell (pg) & $H b / c e l l(p g)$ & $H b / c e l l(p g)$ & $\begin{array}{l}\text { Hb per erythroid } \\
\text { cell }(p g)\end{array}$ & $\begin{array}{l}\text { Hb per erythroid } \\
\text { cell }(p g)\end{array}$ & $\begin{array}{l}\text { Hb per erythroid } \\
\text { cell }(p g)\end{array}$ \\
\hline 6 & BM & 1.12 & 22.5 & 5.0 & 1.18 & 17.7 & 6.7 \\
\hline 7 & $\mathbf{B M}$ & 1.7 & 11.8 & 14.4 & 2.96 & 18.9 & 15.7 \\
\hline 9 & $\mathbf{B M}$ & 0.45 & 16.1 & 2.8 & 0.29 & 18.7 & 1.6 \\
\hline 11 & BM & 0.38 & 17.9 & 2.1 & 0.13 & 18.0 & 0.7 \\
\hline 12 & PB & 2.44 & 30.4 & 8.0 & 0.26 & 18.3 & 1.4 \\
\hline 13 & PB & 0.38 & 7.8 & 4.9 & 0.22 & 14.1 & 1.6 \\
\hline Mean \pm SD & & $1.1 \pm 0.8$ & $17.8 \pm 7.3$ & $6.2 \pm 4.1$ & $0.8 \pm 1.0$ & $17.6 \pm 1.6$ & $4.6 \pm 5.3$ \\
\hline
\end{tabular}

The results are from paired cultures of the marrow and blood of six separate individuals. The CFU-GEMM colonies contained from 13,300 to 43,300 cells per colony, 59-81\% of which were erythroid. Note that CFU-GEMM cultures were carried out in the continuous presence of Mo cell-conditioned medium as a source of BPA. The differences between the means are not statistically significant. * BM, bone marrow; PB, peripheral blood. 


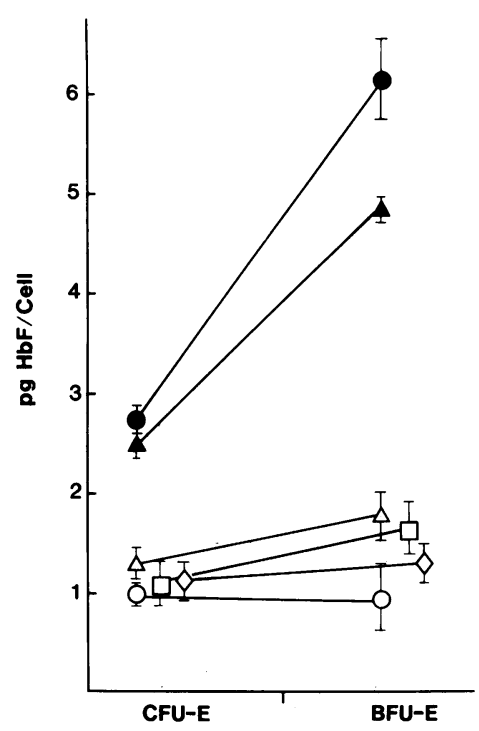

Figure 3. The picograms of $\mathrm{HbF}$ per cell in the marrow BFU-E- and CFU-E-derived colonies of two $M$. fascicularis $(\bullet, \Delta)$ and four humans $(\Delta, \square, \diamond, \diamond)$. The solid bars connect the paired samples. One standard deviation of the triplicate measurements of $\mathrm{HbF}$ is shown. The ranges of the cells per colony were as follows:
CFU-E

239-549

$103-130$
BFU-E

$4.2 \times 10^{3}$ to $32.6 \times 10^{3}$

$3.6 \times 10^{3}$ to $29.1 \times 10^{3}$ per $\mathrm{ml}$, the mean number of BFU-E-derived colonies from four experiments was $55 \pm 6 / 10^{5}$ cells plated with an average colony size of 5,500 cells whereas at $2.0 \mathrm{U}$ erythropoietin/ml there were $128 \pm 54$ colonies $/ 10^{5}$ with an average size of 9,120 cells. However, Fig. $4 \mathrm{~A}$ demonstrates that this 20 -fold increase in erythropoietin concentration and fourfold increase in total erythroid cell production has no effect on the $\mathrm{HbF}$ and $\mathrm{HbA}$ accumulation in the marrow BFU-E-derived colonies. It should be emphasized that this experiment indirectly suggests that exogenous BPA also has no effect on the expression of $\mathrm{HbF}$ in human marrow BFU-E-derived colonies because the eryth-
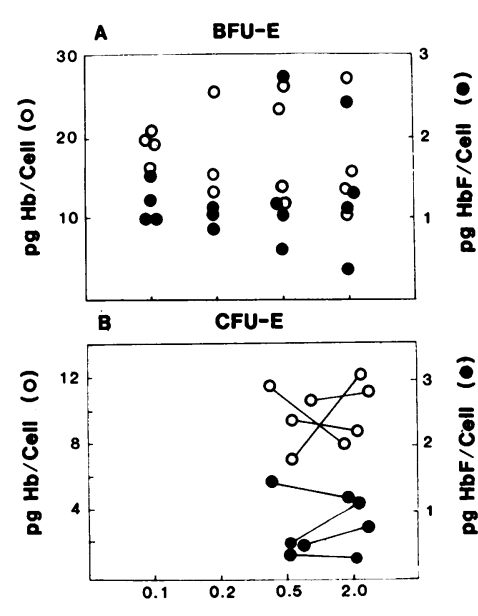

Erythropoletin $(\mathrm{U} / \mathrm{ml})$ erythropoietin on total $\mathrm{Hb}$ and $\mathrm{HbF}$ accumulations in BFU-E-derived colonies. (O) Total hemoglobin in picograms per cell; (๑) $\mathrm{HbF}$ in picograms per cell. The nonlinear abscissa represents the units of erythropoietin utilized in the cultures. $(B)$ Influence of 0.5 and $2 \mathrm{U}$ of erythropoietin on total hemoglobin and HbF accumulation in CFUE-derived colonies. The solid lines connecting points represent pairs of samples cultured at the two different erythropoietin concentrations.
Figure 4. ( $\dot{A})$ Influence of ropoietin used in these experiments (Toyoba) is liberally contaminated with BPA.

The lack of influence of erythropoietin on $\mathrm{HbF}$ accumulation in CFU-E-derived colonies is shown in Fig. $4 \mathrm{~B}$. Here the progenitors were cultured only at 0.5 and $2 \mathrm{U}$ of erythropoietin, because at lower concentrations, the colonies were too small to be plucked effectively. No clear pattern of hemoglobin synthesis emerges from this study of CFU-E culture across a fourfold range of erythropoietin concentrations.

Asynchrony of $\mathrm{HbF}$ and $\mathrm{HbA}$ accumulation. Various groups have shown that there may be marked asynchrony of $\mathrm{HbF}$ and $\mathrm{HbA}$ production with relatively more $\mathrm{HbF}$ synthesis early in culture $(20,21,14)$. Similar asynchrony was demonstrated in this study when erythropoietin addition to the cultures was delayed, but not when erythropoietin was added from the start (data not shown).

To examine this question further; three marrows were cultured with erythropoietin added at the onset of the culture period. On day 12 , all poorly hemoglobinized BFU-E-derived colonies were plucked and pooled and then all the wellhemoglobinized BFU-E were separately harvested and pooled. The average hemoglobin contents of the two pools were then compared. Inasmuch as all categories of erythroid colonies accumulate similar $\mathrm{HbF}$ contents, it was argued that any difference in the percentage of $\mathrm{HbF}$ content between the well and poorly hemoglobinized colonies must be due to asynchrony of hemoglobin production with time. Fig. 5 demonstrates that $\mathrm{HbF}$ accounted for $22.8 \pm 4.4 \%$ of the total hemoglobin in the poorly hemoglobinized BFU-E and only $10.0 \pm 5.6 \%$ in the well-hemoglobinized BFU-E-derived colonies. Despite the changes in the relative proportions of $\mathrm{HbF}$, absolute amounts of $\mathrm{HbF}$ were nearly the same in both types of colonies. Thus, asynchrony and a high fractional $\mathrm{HbF}$ content are features of incomplete hemoglobinization of erythroid colonies.

Expression of the $\mathrm{HbF}$ program in colonies derived from the peripheral blood BFU-E of patients with hemoglobinopathies. After having established conditions in which the capacity to express $\mathrm{HbF}$ in the erythroblasts proximally derived from erythroid progenitors is not detectably influenced by progenitor maturity, we next set out to estimate the $\mathrm{HbF}$ program as it is expressed in the erythroblasts derived from the peripheral blood BFU-E of several individuals with different $\beta$-chain hemoglobinopathies. The results are depicted in Fig. 6. Here it is demonstrated that patients with non- $\delta, \beta$-deletion types of $\beta$-thalassemia have wide variations in their $\mathrm{HbF}$ programs ranging from nearly normal to as high as $5 \mathrm{pg}$ of $\mathrm{HbF}$ per BFU-E-derived erythroblast and that the heterozygous parents

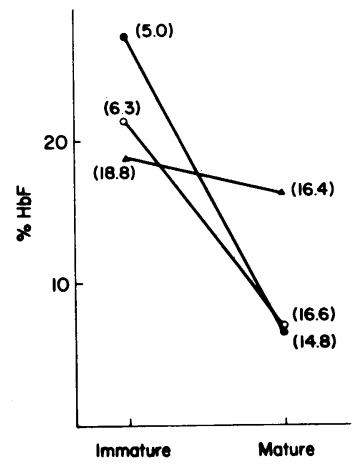

Figure 5. Three separate studies $(\bullet, \circ$, $\Delta)$ of the percentage of $\mathrm{HbF}$ in immature (poorly hemoglobinized) and mature (well-hemoglobinized) marrow BFU-E-derived colonies. The total hemoglobin in picograms per cell for each study is shown in parentheses. Note that the fraction of $\mathrm{HbF}$ declines as total hemoglobin increases and the colonies mature. 


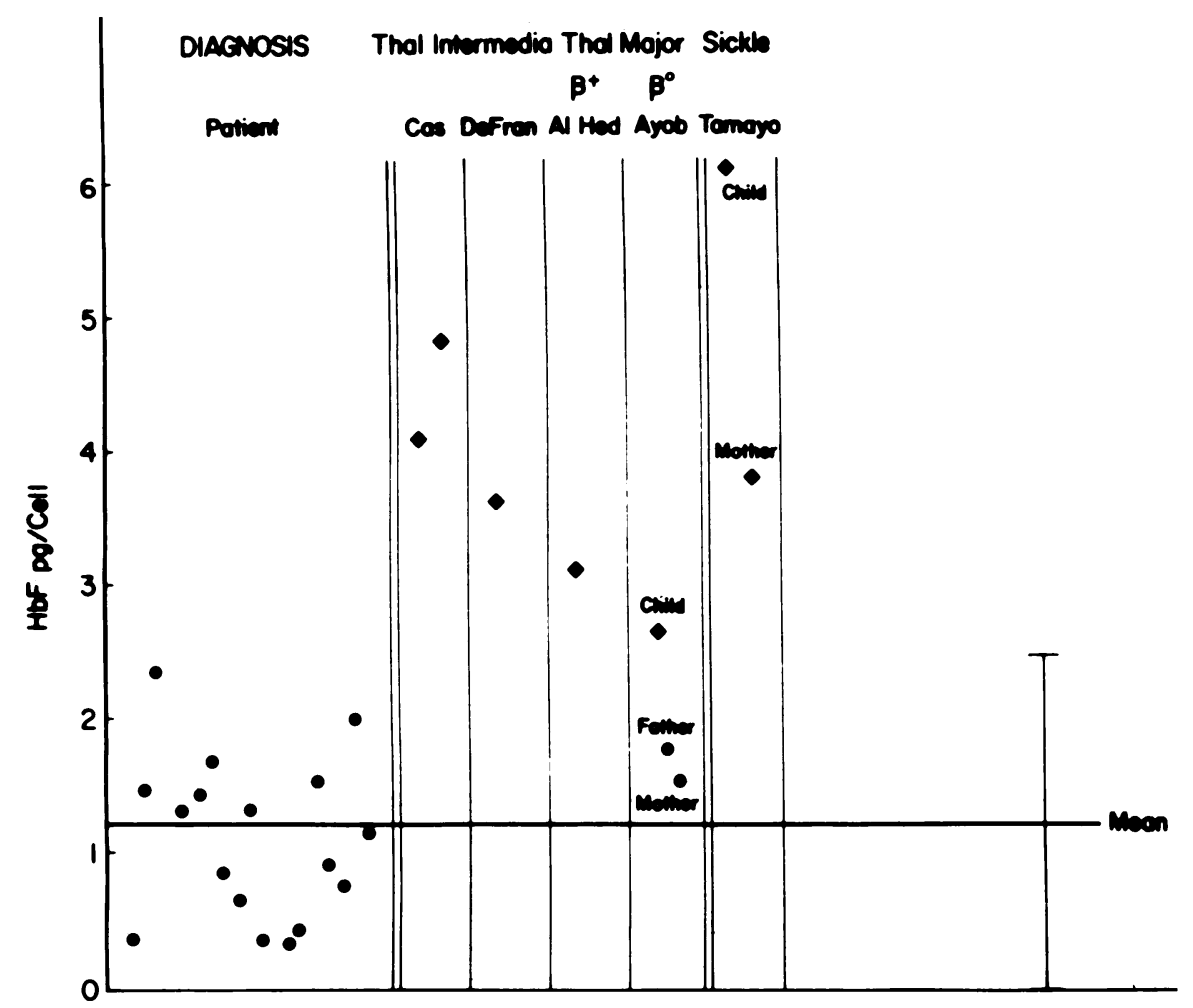

Figure 6. The HbF content of erythroid cells in the peripheral blood BFU-E-derived colonies of patients with hemoglobinopathies $(\bullet)$ or their parents $(\bullet)$. The values and range for normal controls $(\bullet)$ are shown in the lower left corner. The diagnosis for each patient is shown at the top of each column. of a patient with $\beta^{0}$-thalassemia and a nearly normal $\mathrm{HbF}$ program also have normal rather than elevated accumulations of $\mathrm{HbF}$ in the erythroid cells of their BFU-E-derived colonies. In contrast, a patient with sickle cell anemia and a nondeletion form of hereditary persistence of $\mathrm{HbF}$, whose total circulating $\mathrm{HbF}$ was $>30 \%$, had an extraordinarily high $\mathrm{HbF}$ program expressed in peripheral blood BFU-E, as did her mother, a patient with hemoglobin $\mathrm{S}$ trait who, in fact, had $4 \% \mathrm{HbF}$ present in her circulating blood. It is likely that this patient with SS disease inherited a form of hereditary persistence of $\mathrm{HbF}$ as well as a $\beta-\mathrm{S}$ gene from her mother.

None of the above results could be explained by alterations in colony growth. The erythroid cells per colony in the cultures of the patients and family members ranged from 9.3 to 34.6 $\left(\times 10^{3}\right)$ and were very similar in each case to normal controls cultured simultaneously.

\section{Discussion}

This study confirms that the progeny of human erythroid progenitor cells grown in vitro contain more $\mathrm{HbF}$ than is found in marrow erythroblasts or peripheral erythrocytes. However, the average amount of HbF per cell grown in vitro is quite low. In our hands, it varies between 0.13 and $2.96 \mathrm{pg} /$ cell representing between 0.7 and $19.6 \%$ of total hemoglobin in well-hemoglobinized colonies derived from CFU-E, marrow BFU-E, blood BFU-E, and CFU-GEMM. The mean fractional $\mathrm{HbF}$ content of all well-hemoglobinized colonies in all experiments was $7.0 \pm 4.6 \%$ which is considerably less than that reported by many workers who measured hemoglobin synthesis over a single 24-h period in culture (7-11) and is in agreement with the values for the progeny of peripheral blood BFU-E determined by Javid et al. (27) using the same radioligand immunoassay and for those of marrow BFU-E determined by
Dover et al. (26) using a quantitative immunoprecipitation technique. In the latter study, the $\mathrm{HbF} / \mathrm{F}$ cell in marrow BFUE colonies was found to be $6.2 \mathrm{pg}$ but only $40 \%$ of the total cells were $F$ cells as defined in that study.

Whereas in the rhesus monkey (24) and in M. fascicularis the erythroid cells derived from more immature progenitors contain more $\mathrm{HbF}$ (two- to fourfold difference from CFU-E to BFU-E), this is not the case in normal humans, there being no difference under the described experimental conditions between the $\mathrm{HbF}$ contents of the colonies derived from CFUE, marrow BFU-E, blood BFU-E, and CFU-GEMM. Therefore, erythroid differentiation in humans does not appear to recapitulate ontogeny with respect to potential for $\mathrm{HbF}$ production. The studies of Dover et al. (26) have suggested that there is a little less $\mathrm{HbF}$ per $\mathrm{F}$ cell in CFU-E derived colonies compared with colonies derived from BFU-E, whereas we found no significant difference in the average $\mathrm{HbF}$ content per cell in these classes of colonies. This discrepancy may result from differences in culture conditions and indeed the CFU-E-derived colonies grown under our conditions are sometimes larger than those described by Dover et al. (26). Furthermore, the average total hemoglobin content per cell for CFU-E in this study was $11.8 \pm 2.7 \mathrm{pg} /$ cell compared with $16.0 \pm 6.2 \mathrm{pg} / \mathrm{cell}$ in the corresponding marrow BFU-E so that the cells in the CFU-E derived colonies cultured for only $7 \mathrm{~d}$ may have been a little less mature with consequent over estimation of their fractional if not their absolute $\mathrm{HbF}$ content. It should be noted however that no differences were detected in the morphology of the erythroid cell in CFU-E- and BFU-E-derived colonies. What is clear is that in normal humans, the potential for $\mathrm{HbF}$ production in erythroblasts immediately derived from the most primitive progenitors (CFU-GEMM) is very limited and remains constant throughout progenitor maturation. The major step down in $\gamma$-globin gene expression occurs after the CFU- 
E stage of differentiation, probably at a point that is analogous to the highly erythropoietin responsive cell in the simian system (24). We do not know the molecular basis of this step down, but have previously suggested that general understanding of the observation requires quantitative consideration of the numbers of the reticulocytes produced by erythroblasts proximately derived from progenitors (24). Our calculations, based on previously published data persuade us that such reticulocytes represent only a small fraction of the daily reticulocyte production in normal individuals. They may be the precursors of the few $F$ cells found in the normal circulation. In contrast, the majority of circulating erythrocytes, the non-F cells, are products of reticulocytes that were likely to have been derived from proerythroblasts that underwent one or more rounds of quantal division (30) before they completed the process of terminal differentiation. We believe that, as proerythroblasts undergo quantal division in vivo, they must lose their capacity to express the inherent $\mathrm{Hb} F$ program present at the progenitor level. Hence, under normal conditions marrow erythroblasts contain far less $\mathrm{HbF}$ than do erythroblasts immediately derived from progenitors in vitro. Erythropoietic stress is accompanied by a vast increase in the fraction of proerythroblasts proximally derived from progenitors. Quantal division is bypassed in favor of immediate terminal differentiation. Therefore, the $\mathrm{HbF}$ program is retained in a much larger proportion of proerythroblasts and $\mathrm{F}$ reticulocytes and $\mathrm{F}$ cells increase pari passu.

In the primate studies reported by Macklis et al. (24) it was suggested that crude erythropoietin preparations and BPA may modify $\gamma$-globin gene expression, and in previous studies of human BFU-E it was shown that crude erythropoietin (contaminated with BPA) enhanced $\mathrm{HbF}$ synthesis whereas pure erythropoietin had no effect on $\mathrm{HbF}$ synthesis (8). In the study reported here, 20-fold increments of erythropoietin known to be contaminated with BPA increased the incidence and size of progenitor-derived colonies but had no effect on the final $\mathrm{HbF}$ or $\mathrm{HbA}$ content per cell. Clarke and Housman similarly found no effect of crude erythropoietin on $\mathrm{HbF}$ synthesis (19). We conclude that in normal humans, BPA and erythropoietin induce the formation of erythroid colonies, which in turn express the hemoglobin program that is predetermined by the physical chemical state of the globin genes in the progenitor. The hormones and inducers do not selectively modify the globin gene program. Instead, they stimulate the progenitor to begin and complete the process of terminal differentiation. This conclusion does not in any way suggest that globin gene expression cannot be modified in progenitor derived erythroid colonies. Indeed Clarke and co-workers (31) have demonstrated quite the reverse. The cultures employed here must contain the amount of BPA present in calf serum. This might be an amount sufficient to trigger maximally a putative BPA-sensitive $\gamma$-gene expression system. Of considerable interest in this regard are the findings of Javid and Pettis (27) that adherent mononuclear cells can increase the amount of $\mathrm{HbF}$ produced in the colonies derived from the peripheral blood BFU-E of some individuals. The study of Javid and Pettis used optimal culture conditions and assessed hemoglobin content by radioligand immunoassay. As the BFU-E progeny were well hemoglobinized both with and without mononuclear cells, and we have shown that selection of a more primitive BFU-E would not affect the $\mathrm{HbF}$ program, the adherent cells must have had a direct effect on $\gamma$-globin gene expression. We did not detect this effect in the two simian marrow cultures in which we searched for it. Recently, Stamatoyannopoulos and co-workers (32) have reported that a factor in fetal sheep serum can markedly reduce the fractional synthesis of $\mathrm{HbF}$ in human BFU-E-derived colonies. Whether this activity represents a hemoglobin switching factor or a modifier of colony growth that leads to marked enhancement of hemoglobin A production in otherwise underdeveloped colonies is not known.

Considerable attention has been paid to the asynchrony of $\mathrm{HbF}$ and $\mathrm{HbA}$ synthesis over time in vitro and we have been able to show such asynchrony in marrow cultures sampled at an early phase of colony development (Fig. 5). These experiments suggest that under optimal conditions asynchrony is present only in the very earliest stages of progenitor-derived colony growth and that marked asynchrony in the later stages of colony growth is a feature of suboptimal culture conditions. One of the benefits of the radioligand immunoassay used in this study is that the total hemoglobin content per cell can be determined, acting as a check on culture conditions and colony maturity. We would suggest that if the average blood BFU-E size is $<5,000$ cells or the $\mathrm{Hb}$ content per cell $<10 \mathrm{pg} /$ cell, then great caution should be used in interpreting fractional $\mathrm{HbF}$ contents. It is likely that suboptimal culture conditions or the harvesting of colonies prior to full hemoglobinization may have contributed to some of the higher values for relative $\mathrm{HbF}$ synthesis in vitro previously reported. Dean et al. (28) also measured $\mathrm{Hb}$ contents by a radioimmunoassay and found that day 15 bursts contained $25 \% \mathrm{HbF}$. However, the BFU-Ederived colonies analyzed in that study contained fewer cells than in the present study, and the mean corpuscular hemoglobin was $<10 \mathrm{pg}$ per cell.

Alteration of the $\mathrm{HbF}$ program has particular relevance to future treatment of patients with hemoglobinopathies, and the use of cytotoxic/cytostatic drugs to increase $\mathrm{HbF}$ production has aroused much interest $(33,34)$. Cell cycle specific cytotoxic agents would be expected to inhibit erythroblasts or highly erythropoietin responsive cells preferentially (35), forcing the remaining less rapidly cycling progenitor cells to undergo premature terminal differentiation. This perturbation of the progenitor and precursor cell pools might in itself increase $\mathrm{HbF}$ production independent of any drug effect on globin gene function. But the studies reported here also suggest that such a drug effect would induce an increment of $\mathrm{HbF}$ production of only $0.13-2.96 \mathrm{pg} /$ cell or $1-20 \%$ of the mean corpuscular hemoglobin in the erythrocytes of normal individuals.

The HbF program within the erythroid progenitors of patients with nondeletion $B$ chain hemoglobinopathies might differ considerably from that of normal Caucasian volunteers because there is considerable evidence that the $\mathrm{B}$ chain hemoglobinopathies arose in some cases on a chromosome background that differs with respect to the globin gene complex from that of most Caucasians without hemoglobinopathy (36). Some of these gene complexes might induce much higher $\gamma$-gene output in the erythroblasts that proximally arise as a result of the differentiation of progenitors. Indeed the variable fraction of $F$ cells in patients with hemoglobinopathies (36, 37) may be in part related to such a mechanism.

Our preliminary evaluation of patients with various forms of nondeletion $\beta$-thalassemia and sickle cell disease and a very small sample of heterozygotes amply confirms the heterogeneity of the $\mathrm{HbF}$ program in the peripheral blood BFU-E of such patients. Some of the patients and family members produced 
an amount of $\mathrm{HbF}$ in BFU-E-derived colonies that was within the normal range or only slightly higher. Others produced very large amounts of $\mathrm{HbF}$. This evaluation of patients must be considerably expanded and careful family studies carried out to determine the patterns of inheritance of the $\mathrm{HbF}$ program (38-40). Then an approach to the molecular basis of the differences in these programs can be instituted. It will be of particular interest to determine whether the $\mathrm{HbF}$ response to cytotoxic/cytostatic drug therapy in humans is in any way predicted by the intrinsic $\mathrm{HbF}$ program detected in progenitors.

\section{Acknowledgments}

The haptoglobin assays were performed at the Center for Blood Research, Boston, Massachusetts.

This study was supported by grants P01 HL-27375, P01 CA-18662, and S07-RR05399 from the U. S. Public Health Service and a grant from the Dyson Foundation. Dr. Linch is the recipient of a British Medical Research Council Travelling Fellowship.

\section{References}

1. Boyer, S. H., T. K. Belding, L. Margolet, and A. Noyes. 1975. Fetal hemoglobin restriction to a few erythrocytes (F cells) in normal human adults. Science (Wash. DC). 185:361-363.

2. Weatherall, D. J., J. B. Clegg, and W. G. Wood. 1976. A model for the persistence or reactivation of fetal hemoglobin production. Lancet. 2:660-661.

3. Gabuzda, T. G., D. G. Nathan, and F. H. Gardner. 1963. The turnover of hemoglobins $\mathrm{A}, \mathrm{F}$ and $\mathrm{A}_{2}$ in the peripheral blood of three patients with thalassemia. J. Clin. Invest. 42:1678-1688.

4. Nathan, D. G., and R. B. Gunn. 1966. Thalassemia: the consequences of unbalanced hemoglobin synthesis. Am. J. Med. 41: 815-830.

5. Hall, J. G., and A. G. Motulsky. 1968. Production of fetal haemoglobin in marrow cultures of human adults. Nature (Lond.). 217:569-571.

6. Papayannopoulou, Th., M. Brice, and G. Stamatoyannopoulos. 1977. Hemoglobin F synthesis in vitro: evidence for control at the level of primitive erythroid stem cells. Proc. Natl. Acad. Sci. USA. 74: 2923-2927.

7. Kidoguchi, K., M. Ogawa, and J. D. Karam. 1979. Hemoglobin biosynthesis in individual erythropoietic bursts in culture. J. Clin. Invest. 63:804-806.

8. Terasawa, T., M. Ogawa, P. N. Porter, D. W. Golde, and E. Goldwasser. 1980. Effect of burst promoting activity (BPA) and erythropoietin on hemoglobin biosynthesis in culture. Blood. 56:11061110.

9. Weinberg, R. S., J. D. Goldberg, J. M. Schofield, A. L. Lenes, R. Styczynski, and B. P. Alter. 1983. Switch from fetal to adult hemoglobin is associated with a change in progenitor cell population. J. Clin. Invest. 71:785-794.

10. Papayannopoulou, Th., B. Nakomoto, J. Buckley, S. Kurachi, P. E. Nute, and G. Stamatoyannopoulos. 1978. Erythroid progenitors circulating in the blood of adult individuals produce fetal hemoglobin in culture. Science (Wash. DC). 199:1349-1350.

11. Clarke, B. J., D. G. Nathan, B. P. Alter, B. G. Forget, D. G. Hillman, and D. Housman. 1979. Hemoglobin synthesis in human BFU-E and CFU-E derived erythroid colonies. Blood. 54:805-817.

12. Peschle, C., A. Covelli, F. Lettieri, A. R. Migliaccio, G. Migliaccio, P. Comi, M. L. Pozzoli, B. Giglioni, S. Ottolenghi, M. D. Capellini, E. Polli, and A. M. Gianni. 1980. Hemoglobin synthesis in individual bursts from normal adult blood: all bursts and subcolonies synthesize $\mathrm{G}$ and $\mathrm{A}$ gamma globin chains. Blood. 56:218-226.

13. Huisman, T. H. J., A. L. Reese, M. E. Gravely, J. B. Wilson, B. Webber, and A. E. Felice. 1980. Adult and fetal hemoglobin production in erythroid colonies from subjects with $\beta$-thalassaemia or with hereditary persistence of fetal hemoglobin (HPFH). Hemoglobin. 4:449-467.

14. Darbre, P. D., S. M. Lauckner, J. W. Adamson, W. G. Wood, and D. J. Weatherall. 1981. Hemoglobin synthesis in human erythroid bursts during ontogeny: reproducibility and sensitivity to culture conditions. Br. J. Haematol. 48:237-250.

15. Fauser, A. A., and H. A. Messner. 1979. Fetal hemoglobin in mixed hemopoietic colonies (CFU-GEMM) erythroid bursts (BFU-E) and erythroid colonies (CFU-E): assessment by radioimmune assay and immunofluorescence. Blood. 54:1384-1394.

16. Kidoguchi, K., M. Ogawa, J. D. Karam, and A. G. Martin. 1978. Augmentation of fetal hemoglobin $(\mathrm{HbF})$ synthesis in culture of human erythropoietic precursors the marrow and peripheral blood: studies in sickle cell anaemia and nonhaemoglobinopathic adults. Blood. 52:1115-1124.

17. Vainchenker, W., U. Testa, N. Hinard, Y. Beuzard, A. Dubart, A. Tsapis, N. Monplaisir, P. Rouyer-Fessard, and J. Rosa. 1980. Hemoglobin synthesis in 7-day and 14-day old erythroid colonies from the bone marrow of normal individuals. Hemoglobin. 4:53-67.

18. Comi, P., M. L. Giglioni, S. Pozzoli, S. Ottlenghi, A. M. Gianni, A. R. Migliaccio, G. Migliaccio, F. Lettieri, and C. Peschle. 1981. Biosynthesis of globin chains in fetal liver and adult marrow cultures. Exp. Cell Res. 133:347-356.

19. Clarke, B. J., and D. Housman. 1978. Kinetics of fetal hemoglobin production by human peripheral blood BFU-E Blood. 52: (Suppl.)201. (Abst.)

20. Papayannopoulou, Th., B. Nakamoto, S. Kurachi, and G. Stamatoyannopoulos. 1981. Globin synthesis in erythroid bursts that mature sequentially in culture. Studies in culture of adult peripheral blood BFU-Es. Blood. 58:969-974.

21. Dover, G. J., and S. H. Boyer. 1980. Quantitation of hemoglobin within individual red cells. Asynchronous biosynthesis of fetal and adult hemoglobin during erythroid maturation in normal subjects. Blood. 56:1082-1091.

22. Wood, W. G., and R. W. Jones. 1981. Erythropoiesis and hemoglobin production: a unifying model involving sequential gene activation. In Hemoglobins in Development and Differentiation. G. Stamatoyannopoulos and A. W. Nienhuis, editors. Alan R. Liss, New York. 243-261.

23. Javid, J., P. K. Pettis, and J. E. Miller. 1981. Radio-ligand immunoassay for human hemoglobin variants. J. Immunol. Methods. 41:247-255.

24. Macklis, R. M., J. Javid, J. M. Lipton, M. Kudisch, P. K. Pettis, and D. G. Nathan. 1982. Synthesis of hemoglobin F in adult simian erythroid progenitor-derived colonies. J. Clin. Invest. 70:752761.

25. Beverley, P. C. L., D. C. Linch, and D. Delia. 1980. Isolation of human haematopoietic progenitor cells using monoclonal antibodies. Nature (Lond.). 287:332.

26. Dover, G. J., T. Chan, and F. Sieber. 1983. Fetal hemoglobin production in cultures of primitive and mature human erythroid progenitors: differentiation affects the quantity of fetal hemoglobin produced per fetal-hemoglobin-containing cell. Blood. 61:1242-1246.

27. Javid, J., and P. K. Pettis. 1983. Fetal hemoglobin synthesis in vitro: the effect of adherent mononuclear cells. J. Clin. Invest. 71 : 1356-1365.

28. Dean, A., A. N. Schechter, Th. Papayannopoulou, and G. Stamatoyannopoulos. 1981. Heterogeneity of erythroid precursor cells. Hemoglobin quantitation in single clones by radioimmunoassay. $J$. Biol. Chem. 256:2447-2453.

29. Lipton, J. M., E. L. Reinherz, M. Kudisch, P. L. Jackson, S. F. Schlossman, and D. G. Nathan. 1980. Mature bone marrow erythroid burst-forming units do not require $T$ cells for induction of erythropoietin dependent differentiation. J. Exp. Med. 152:350-360.

30. Holtzer, H., J. Biehl, P. Antin, S. Tokunaka, J. Sasse, M. Pacifici, and S. Holtzer. 1983. Quantal and proliferative cell cycles: how lineages generate cell diversity and maintain fidelity. In Globin 
Gene Expression and Hematopoietic Differentiation. G. Stamatoyannopoulos and A. W. Nienhuis, editors. Alan R. Liss, New York. 134: 213-227.

31. Clarke, B. J., A. M. Brickenden, R. A. Ives, and H. K. Chui. 1982. Effect of modulators of erythropoiesis on the hemoglobinization of human erythroid cell cultures. Blood. 60:346-351.

32. Stamatoyannopoulos, G., B. Nakamoto, S. Kurachi, and T. Papayannopoulou. 1983. Direct evidence for interaction between human erythroid progenitor cells and a hemoglobin switching activity present in fetal sheep serum. Proc. Natl. Acad. Sci. USA. 80:5650-5654.

33. Ley, T. J., J. DeSimone, N. P. Anagnou, C. Noguchi, P. Turner, A. Schechter, P. Heller, and A. W. Nienhuis. 1982. 5azacytidine selectivity increases $\gamma$-globin synthesis in a patient with B thalassemia. N. Engl. J. Med. 307:1469-1475.

34. Charache, S., G. J. Dover, K. D. Smith, and C. C. Talbot. 1983. Treatment of sickle cell anemia with azacytidine results in increased fetal hemoglobin production and is associated with nonrandom hypomethylation of DNA around the $\gamma-\delta-\beta$ globin gene complex. Proc. Natl. Acad. Sci. USA. 80:4842-4846.
35. Iscove, N. N. 1977. The role of erythropoietin in the regulation of population size and cell cycling of early and late erythroid precursors in mouse bone marrow. Cell Tissue Kinet. 10:323-334.

36. Orkin, S. H., S. E. Antonarakis, and H. H. Kazazian. 1983. Polymorphism and molecular pathology of the human beta-globin gene. Prog. Hematol. 13:49-73.

37. Wood, W. G., G. Stamatoyannopoulos, G. Lim, and P. E. Nute. 1975. F cells in the adult: normal values and levels in individuals with hereditary and acquired elevations of HbF. Blood. 46:671-682.

38. Dover, G. J., S. H. Boyer, S. Charache, and K. Heintelman. 1978. Individual variation in the production and survival of $F$ cells in sickle cell disease. $N$. Engl. J. Med. 299:1428-1435.

39. Zago, M. A., W. G. Wood, J. B. Clegg, D. J. Weatherall, M. O'Sullivan, and H. Gunson. 1979. F cells in human adults. Blood. 53: 977-986.

40. Milner, P. F., J. Leibfarth, J. Ford, B. Barton, H. E. Grenett, and F. A. Garver. 1983. Increased $\mathrm{HbF}$ in sickle cell anemia is determined by a factor linked to the $\beta^{s}$ gene from one parent. Blood. 63:64-72. 